\title{
Mathematical modeling of a solid oxide fuel cell operating on biogas
}

\author{
Wandercleiton Cardoso ${ }^{1}$, Renzo di Felice $^{2}$, Raphael Colombo Baptista ${ }^{3}$ \\ ${ }^{1,2}$ Department of Civil, Chemical and Environmental Engineering, University of Genoa, Italy \\ ${ }^{3}$ Graduate Program in Metallurgical and Materials Engineering, Federal Institute of Espírito Santo, Brazil
}

\section{Article Info \\ Article history: \\ Received Jul 25, 2021 \\ Revised Oct 11, 2021 \\ Accepted Oct 20, 2021}

\section{Keywords:}

Biogas

Fuel cell

Methane

Renewable biofuel

SOFC

\begin{abstract}
Solid oxide fuel cells (SOFC) are the most efficient devices for directly converting the chemical energy of a fuel into electrical energy. This is one of the main reasons why these fuel cells have received a lot of attention from the scientific community and from several developers who have invested in the use of this technology in various applications. Biogas is one of the products of anaerobic decomposition (absence of gaseous oxygen) of organic matter, which occurs due to the action of certain types of bacteria. Biogas is mainly composed of methane $\left(\mathrm{CH}_{4}\right)$ and carbon dioxide $\left(\mathrm{CO}_{2}\right)$ and its use in solid oxide fuel cells has been investigated since Biogas is a renewable biofuel. The aim of this paper was to perform mathematical modeling of a solid oxide fuel cell operating on biogas. The results confirmed that the overall efficiency of the system is above $94 \%$ and the largest irreversibilities of the system are related to heat exchangers.
\end{abstract}

This is an open access article under the CC BY-SA license.

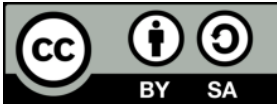

\section{Corresponding Author:}

Wandercleiton Cardoso

Department of Civil, Chemical and Environmental Engineering

University of Genoa

Via Montallegro, 1-16145 Genoa, Italy

Email: wandercleiton.cardoso@dicca.unige.it

\section{NOMENCLATURE}

\begin{tabular}{|c|c|c|c|}
\hline$\psi$ & : Bosnjakovic efficiency & MM & Molar mass \\
\hline$\lambda$ & : Excess air & $n$ & : Number of individual SOFC cells \\
\hline$c_{\mathrm{p}}$ & : Constant pressure & Q & Heat transfer rate \\
\hline $\mathrm{CV}$ & Volume control & $\mathrm{Qcv}_{\mathrm{cv}}$ & Heat transfer rate for control volume \\
\hline & : Electron & $\mathrm{S}$ & Specific entropy \\
\hline EF & : Electromotive force & $\mathrm{S} / \mathrm{C}$ & Steam to carbon ratio \\
\hline $\mathrm{G}$ & : Gibbs free energy & $\mathrm{S}_{0}$ & Specific enthalpy \\
\hline & : Specific enthalpy & $\mathrm{T}$ & Temperature \\
\hline$h_{0}$ & : Specific enthalpy & $\mathrm{V}$ & Volume \\
\hline input & Input specific enthalpy & $\mathrm{W}$ & Work \\
\hline utput & : Output specific enthalpy & $\mathrm{W}_{\mathrm{cv}}$ & Work on control volume \\
\hline & : Specific enthalpy of formation & $\mathrm{x}_{n}$ & Number of moles \\
\hline LHV & : Lower Heating Value & $\Delta \mathrm{G}$ & Gibbs energy difference \\
\hline & : Formation Gibbs energy difference & Ex & Exergy current \\
\hline & : Enthalpy difference & $e x$ & Specific exergy \\
\hline $\mathrm{h}$ & : Enthalpy of formation & $e x_{\text {input }}$ & Input specific exergy \\
\hline & : Entropy difference & $e x_{\text {output }}$ & Specific output exergy \\
\hline
\end{tabular}




$\begin{array}{ll}E x & : \text { Exergy current } \\ e x & : \text { Specific exergy } \\ e x_{\text {input }} & : \text { Input specific exergy } \\ e x_{\text {output }} & : \text { Specific output exergy } \\ m & : \text { Mass flow } \\ m_{\text {input }} & : \text { Input mass flow } \\ m_{\text {output }} & : \text { Output mass flow } \\ \eta_{\text {elec }} & : \text { Electrochemical efficiency }\end{array}$

$\begin{array}{ll}\eta_{\text {thermo }} & : \text { Thermodynamic efficiency } \\ \eta_{c c} & : \text { Efficiency of conventional boiler } \\ \eta_{\text {comp }} & : \text { Compressor efficiency } \\ \eta_{\text {electrical }} & : \text { 1st Law electricity generation efficiency } \\ \eta_{\text {global }} & : \text { 1st and } 2 \text { nd Law global efficiency } \\ \eta_{\text {ratical }} & : \text { Practical efficiency } \\ \eta_{\text {termical }} & : \text { 1st Law Thermal Efficiency } \\ \mu_{f} & : \text { Fuel usage factor }\end{array}$

\section{INTRODUCTION}

A fuel cell is a technology that uses hydrogen and oxygen to generate electricity and hot water vapor produced by the chemical process in the fuel cell. The electrical energy produced in the fuel cell is highly efficient, emits no pollutants, and is silent. Hydrogen is its main fuel. This fuel can be obtained from various renewable sources and also from fossil resources, but with much lower environmental impact [1], [2].

In the future, fuel cells will be a solution for electricity generation at the point of consumption, in industry, households and shopping malls, in addition to being used in cars, airplanes, motorcycles, busses and portable devices such as mobile phones and laptops [3]. Biogas is a very interesting fuel for use in fuel cells, especially fuel cells that operate at high temperatures such as solid oxide fuel cells (SOFC). Biogas is a gas produced by the anaerobic decomposition of organic matter (in the absence of oxygen) under suitable conditions of temperature, pressure, and humidity [4], [5]. Biogas consists of methane gas $\left(\mathrm{CH}_{4}\right)$ and carbon dioxide $\left(\mathrm{CO}_{2}\right)$ and also contains hydrogen sulfide $\left(\mathrm{H}_{2} \mathrm{~S}\right)$, nitrogen $\left(\mathrm{N}_{2}\right)$, water $\left(\mathrm{H}_{2} \mathrm{O}\right)$, and ammonia $\left(\mathrm{NH}_{3}\right)$ in smaller proportions in its composition [6], [7].

Recent studies on fuel cells aim to develop systems that use non-traditional fuels. The purpose of these new studies is to develop new energy and electricity generators that use renewable fuels for applications such as heating in homes, fuel for cars (biomethane), injection in blast furnaces to replace nonrenewable fuels (coke and coal) and noble applications in fuel cells. Solid oxide fuel cells can run on various fuels such as hydrogen, syngas, natural gas, biomethane and biogas [8], [9].

The solid oxide fuel cell consists of five elements: cathode, anode, electrolyte and two connecting elements which are all solid. In this type of device, the electrolyte consists of a ceramic that conducts oxide ions from the cathode to the anode. The operating temperature is between $600^{\circ} \mathrm{C}$ and $1000^{\circ} \mathrm{C}$, while the oxygen ions, $\mathrm{O}_{2}^{-}$, are transported through the electrolyte to the anode, where the fuel is oxidized to produce water. For hydrogen fuel, the chemical reactions in the solid oxide fuel cell (SOFC) are described in (1) to (3) as shown in. These chemical reactions represent the anodic reaction, cathodic reaction, and global reaction, respectively [4], [10], [11].

$$
\begin{aligned}
& \mathrm{H}_{2}+\mathrm{O}^{2-} \rightarrow \mathrm{H}_{2} \mathrm{O}+2 e^{-} \\
& \frac{1}{2} \mathrm{O}_{2}+2 e^{-} \rightarrow \mathrm{O}^{2-} \\
& \mathrm{H}_{2}+\frac{1}{2} \mathrm{O}_{2} \rightarrow \mathrm{H}_{2} \mathrm{O}
\end{aligned}
$$

Looking at the cell structure, there are basically 2 types of solid oxide fuel cells: planar or tubular. The planar model has square or rectangular flat cell modules consisting of an interconnector, an anode, an electrolyte, and a cathode. In the tubular model, the electrode (cathode or anode) is in the form of a long tube with a porous wall and on the outside of this tube is the electrolyte and another electrode. The tubular model is the most widely used and researched, so the technology of the tubular model is more advanced and widespread than that of the planar model. The tubular model is most suitable for large area applications [12]. Figure 1 illustrates a tubular solid oxide fuel cell.

The solid oxide fuel cell can be fed with biogas by direct or indirect injection. In indirect feeding, the biogas is upgraded beforehand to form a hydrogen-rich gas mixture [13], [14]. This indirect injection technique is also known as reformed biogas injection. In this context, biogas reforming processes contribute to fuel cell performance because this reformed gas has properties and operating requirements that minimize equipment degradation [12], [15]. 


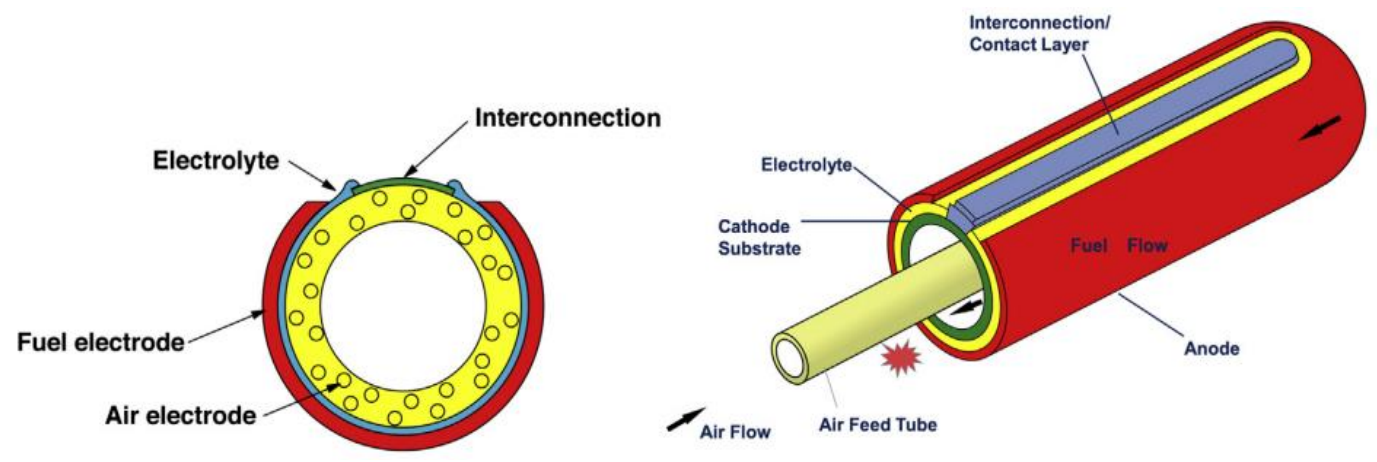

Figure 1. A schematic of single cathode-supported tubular SOFC

There are three processes for reforming a fuel: 1) steam reforming, 2) partial oxidation, and 3) autothermal reforming. Steam reforming is a simple technology with low production cost and is probably the most widely used method for $\mathrm{H}_{2}$ production [7], [16], [17]. The chemical reactions of biogas steam reforming are listed as shown in.

$$
\begin{aligned}
& \mathrm{CH}_{4}+\mathrm{H}_{2} \mathrm{O} \rightarrow \mathrm{CO}+3 \mathrm{H}_{2} \Delta_{f} H^{\circ}=206[\mathrm{~kJ} / \mathrm{mol}] \\
& \mathrm{CO}+\mathrm{H}_{2} \mathrm{O} \rightarrow \mathrm{CO}_{2}+\mathrm{H}_{2} \Delta_{f} H^{\circ}=-41[\mathrm{~kJ} / \mathrm{mol}] \\
& \mathrm{CH}_{4}+2 \mathrm{H}_{2} \mathrm{O} \rightarrow \mathrm{CO}_{2}+4 \mathrm{H}_{2} \Delta_{f} H^{\circ}=165[\mathrm{~kJ} / \mathrm{mol}]
\end{aligned}
$$

Steam reforming of biogas begins with (4), in which the hydrocarbon molecule decomposes to carbon monoxide and hydrogen after reacting with steam in a catalytic bed. This reaction is endothermic and occurs only at high temperatures. At the same time, the carbon monoxide reacts with the water vapour to form carbon dioxide and hydrogen as shown in (5). The overall reaction is shown in (6). In (4) to (6) can take place outside the fuel cell in a special reformer or inside the fuel cell, since the temperature required for the chemical reaction corresponds to the operating temperature of the fuel cell [14]-[19].

Fuel reforming can be direct or indirect. In fuel cells, fuel reforming takes place at the inlet of the cell without the need to install an external device. In indirect internal reforming, the electrochemical reactions take place spatially separated while the cell provides heat through radiation or direct physical contact, whereas in direct internal reforming, the fuel mixture (hydrocarbon/steam) is admitted directly into the anode compartment and the fuel is reformed in the porous anode layer.

The supply of steam to ensure the reforming reaction is carried out with an auxiliary device for steam generation, e.g. by a recovery boiler heat recovery steam generator (HRSG) or it is also possible to use the steam generated by the fuel cell electrochemical reaction and the anodic exhaust gas recirculation device [3], [4], [20]-[22]. The first method can be used in both external and internal reforming and requires a steam supply directed to the anode. The disadvantage of this method is the high cost of implantation in the power generation system. The second alternative is to use the steam generated during the electrochemical reaction by means of an ejector located near the gas outlet of the anode compartment. Steam must be directed to the focal point before both enter the cell.

Therefore, anodic recirculation is only an internal reforming process. Although the steam reforming process is able to produce a hydrogen-rich gas mixture and contribute positively to the operating efficiency, it also presents a problem point in terms of durability, namely the deposition of carbon in the fuel cell [17][23]. The risk of carbon deposition on the anode surface at high operating temperatures can reduce the fuel cell performance and lifetime. The parameters that affect carbon deposition are the steam-to-carbon (S/C) ratio and the temperature of the reforming reaction. The $\mathrm{S} / \mathrm{C}$ ratio is explained by the molar flux of steam $\left(n \mathrm{H}_{2} \mathrm{O}\right)$ used in the reaction and the molar flux of methane $\left(n \mathrm{CH}_{4}\right)$ of the fuel, as shown in (7).

$$
\frac{S}{C}=\frac{\dot{n} H_{2} \mathrm{O}}{\dot{n} \mathrm{CH}_{4}}
$$

Fuel reforming is carried out between $400^{\circ} \mathrm{C}$ and $1000^{\circ} \mathrm{C}$, but it is necessary to operate at higher temperatures so that the risk of carbon deposition is lower. According to literature [8], [17], there are several works describing the ternary diagram of the molar composition of carbon, hydrogen and oxygen $(\mathrm{C}-\mathrm{H}-\mathrm{O})$, 
which illustrates the experiments of the composition of chemical components during the reforming of biogas. In their experiments, it is observed that the higher the temperature during fuel reforming, the larger the equilibrium range of elemental composition $(\mathrm{C}-\mathrm{H}-\mathrm{O})$ and the lower the probability of carbon deposition problems.

In the literature, several authors recommend the use of a steam to carbon ratio of 1.5 to 5 to avoid carbon deposits. In a study [24], [25] to analyze the molar fractions of biogas steam reforming products at three different steams to carbon ratios $\left(\mathrm{S} / \mathrm{C}=2,3\right.$, and 4), it was found that the $\mathrm{H}_{2}$ concentration is inversely proportional to the steam to carbon ratio, while the mass flow rate is directly proportional to the steam to carbon ratio. That is, even though the $\mathrm{H}_{2}$ concentration in the reformed mixture decreases, when the steam to carbon ratio increases, the hydrogen production is higher because more hydrogen is added to the process in the form of steam $\left(\mathrm{H}_{2} \mathrm{O}\right)$ [8], [24]. The author confirmed the results of the experiment by analyzing the amount of hydrogen produced in relation to the amount of methane consumed in the fuel reforming process [25]. The results of this experiment can be seen in Table 1.

Table 1. Relationships between hydrogen production and consumption of methane

\begin{tabular}{cccc}
\hline Temperature $\left[{ }^{\circ} \mathrm{C}\right]$ & $\mathrm{S} / \mathrm{C}=2$ & $\mathrm{~S} / \mathrm{C}=3$ & $\mathrm{~S} / \mathrm{C}=4$ \\
\hline 700 & 2.33 & 2.82 & 3.15 \\
800 & 2.98 & 3.27 & 3.42 \\
900 & 3.15 & 3.30 & 3.21 \\
1.000 & 3.16 & 3.27 & 3.35 \\
1.100 & 3.14 & 3.24 & 3.31 \\
1.200 & 3.13 & 3.21 & 3.28 \\
\hline
\end{tabular}

This paper aims to evaluate the performance of a cogeneration system and to perform mathematical modeling of a solid oxide fuel cell (SOFC) operating on biogas. In addition, a steam reforming process was internally investigated in the cell to promote a hydrogen-rich gas mixture for operation. In the technical analysis, the first task was to determine the steam to carbon ratio of the internal reforming process, and then to determine the efficiencies of the solid oxide fuel cell and perform energetic and exergetic calculations to obtain the overall efficiency of the system.

\section{RESEARCH METHOD}

The system studied in this paper consists of a solid oxide fuel cell that simultaneously generates electricity and useful heat $\left(60^{\circ} \mathrm{C}\right.$ hot water). The high-temperature exhaust gasses from the SOFC are used for additional energy generation and for heating and/or cooling (combined heat and power).

\subsection{Cogeneration system}

The selected solid oxide cell model is manufactured by Siemens/Westinghouse. The operating parameters of the fuel cell are described in Table 2. The function of the cogeneration unit is to produce electricity and hot water from the heat of the exhaust gases. The fuel cell is fed with biogas, which is then reformed at the inlet of the cell, producing a hydrogen-rich gas mixture. The system has an anodic recirculation system that provides the steam necessary for fuel reforming. The combustor burns unused fuel in the anode of the fuel cell, maximising the temperature of the exhaust gases. The combustion uses air from the cathode as the air injection rate is provided in excess. The exhaust gases have a temperature of $900^{\circ} \mathrm{C}$ and at the exit of the combustion chamber it exceeds $1,100^{\circ} \mathrm{C}$. This heat is used to raise the fuel temperature at the anode inlet and generate useful heat (hot water). Two heat exchangers are used to generate hot water. One heat exchanger is located at the fuel cell to use the heat, while another heat exchanger is positioned at the end of the stream to use the heat from the exhaust gases. The configuration of the system studied is shown in Figure 2, while Table 3 provides information on the identification of the substances at each point of the system, temperatures, pressures and mass flow rates.

Table 2. SOFC operating parameters

\begin{tabular}{lc}
\hline \multicolumn{1}{c}{ Output power } & $100 \mathrm{~kW}$ \\
\hline Cell number & 444 \\
Operating temperature & $900^{\circ} \mathrm{C}$ \\
Electromotive force of a single cell & 0.701 \\
Fuel utilization factor & $80 \%$ \\
\hline
\end{tabular}

Bulletin of Electr Eng \& Inf, Vol. 10, No. 6, December 2021 : 2929 - 2942 


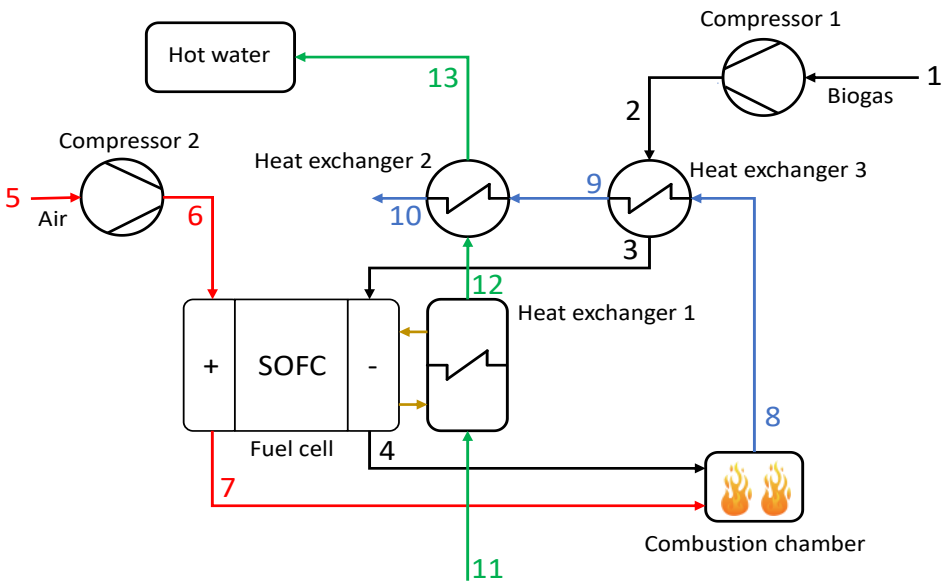

Figure 2. Proposed cogeneration system

Table 3. Substance, temperature, pressure and mass flow of each stream

\begin{tabular}{ccccc}
\hline Stream & Substance & Temperature $\left({ }^{\circ} \mathrm{C}\right)$ & Pression $(\mathrm{kPa})$ & Mass flow $(\mathrm{g} / \mathrm{s})$ \\
\hline 1 & Biogas & 25.0 & 101.325 & 10.5 \\
2 & Biogas & 34.1 & 116.524 & 10.5 \\
3 & Biogas & 700.0 & 101.325 & 10.5 \\
4 & Exhaust gases & 900.0 & 101.325 & 22.3 \\
5 & Air & 25,0 & 101.325 & 101.5 \\
6 & Air & 40.3 & 116.524 & 101.5 \\
7 & Air (SOFC) & 900.0 & 101.325 & 89,7 \\
8 & Exhaust gases & 1173.7 & 101.325 & 112.0 \\
9 & Exhaust gases & 944.3 & 101.325 & 112.0 \\
10 & Exhaust gases & 140.1 & 101.325 & 112.0 \\
11 & Water & 25.0 & 101.325 & 526,8 \\
12 & Water & 36.4 & 101.325 & 526,8 \\
13 & Water & 60.3 & 101.325 & 526,8 \\
\hline
\end{tabular}

\subsection{Biogas composition}

The biogas used in the mathematical modeling contains $60 \%$ methane $\left(\mathrm{CH}_{4}\right)$ and $40 \%$ carbon dioxide $\left(\mathrm{CO}_{2}\right)$, according to the parameters shown in Table 4.

Table 4. Biogas composition

\begin{tabular}{ccccc}
\hline Component & Volume $(\%)$ & Molar mass $(\mathrm{kg} / \mathrm{kmol})$ & Mass $(\%)$ & Lower Heating Value (LHV) $(\mathrm{kJ} / \mathrm{kg})$ \\
\hline Methane $\left(\mathrm{CH}_{4}\right)$ & 60 & 16.04 & 35,35 & 50.010 \\
Carbon dioxide $\left(\mathrm{CO}_{2}\right)$ & 40 & 44.01 & 64,35 & 0 \\
TOTAL & 100 & 27.23 & 100 & 17687.54 \\
\hline
\end{tabular}

\subsection{Steam to carbon rate}

The internal steam reforming process in this paper aims to produce the largest amount of hydrogen $\left(\mathrm{H}_{2}\right)$ for the fuel cell electrochemical reaction. According to literature [25], [26], it was shown in an experiment that the larger the steam to carbon $(\mathrm{S} / \mathrm{C})$ ratio, the larger the mass flow rate of hydrogen present in the reformed fuel for the same mass flow rate of methane introduced in the process. Several publications [7], [17], [21]-[26] recommend the use of a steam to carbon ratio of 1.5 to 5 to avoid carbon deposits. Analysis of the literature shows that when a $(\mathrm{S} / \mathrm{C}$ ratio=4) is used, the mass flow rate of steam required for fuel reforming is greater than the mass flow rate of steam at the anode, making the use of this ratio impractical given the cogeneration proposed in Figure 2.

For the $(S / C=3)$ and $(S / C=2)$ scenarios, anodic steam recirculation is effective to perform fuel reforming without the need for auxiliary supply. The rate $(\mathrm{S} / \mathrm{C}=3)$ guarantees a greater production of hydrogen since it has a greater mass flow rate [27]. In this configuration, the molar concentrations of the internal steam inlets of the reforming have the proportions $1.5 / 1.0 / 7.5$ for $\mathrm{CH}_{4} / \mathrm{CO}_{2} / \mathrm{H}_{2} \mathrm{O}$ (steam). The evaluation of the chemical balance of the fuel reforming process was performed using STANJAN software provided by Colorado State University. STANJAN is an online platform that uses Gibbs free energy 
minimization algorithms to determine the chemical balance, where it is possible to obtain the molar fraction of chemical species in the products.

The hydrogen production has a higher $\mathrm{H}_{2}$ concentration when the reforming temperature is about $700^{\circ} \mathrm{C}$, considering the above molar fractions. In this paper the fuel cell is operated at $900^{\circ} \mathrm{C}$ with a slightly lower $\mathrm{H}_{2}$ concentration, but the $\mathrm{CO}$ concentration is slightly higher. The reformed fuel has the gas composition shown in Table 5, while the mass flow result for the $(\mathrm{S} / \mathrm{C}=3)$ scenario is shown in Figure 3.

Table 5. Molar concentrations of reform products

\begin{tabular}{lc}
\hline \multicolumn{1}{c}{ Component } & Molar fraction \\
\hline Methane $\left(\mathrm{CH}_{4}\right)$ & 0.000 \\
Hydrogen $\left(\mathrm{H}_{2}\right)$ & 0.094 \\
Water $\left(\mathrm{H}_{2} \mathrm{O}\right)$ & 0.444 \\
Carbon oxide $(\mathrm{CO})$ & 0.098 \\
Carbon dioxide $\left(\mathrm{CO}_{2}\right)$ & 0.364 \\
TOTAL & 1.000 \\
\hline
\end{tabular}

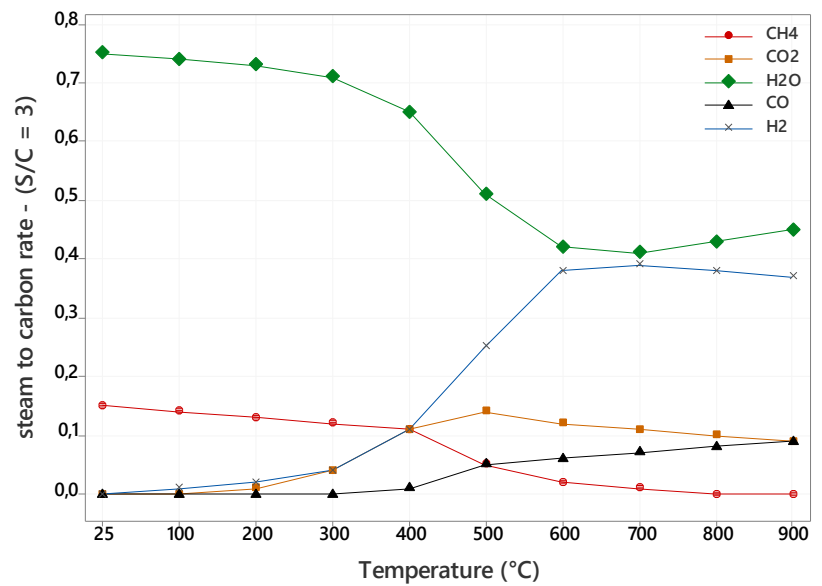

Figure 3. Stem to carbon rate $(\mathrm{S} / \mathrm{C}=3)$

\subsection{Calculation of mass flow rates}

Second [28], in a SOFC, when fed with biogas, the reduction of oxygen takes place at the cathode, as shown in (8), while the reactions taking place at the anode are represented by (8) to (11).

$$
\begin{aligned}
& \mathrm{O}_{2}+4 e^{-} \rightarrow 2 \mathrm{O}^{2-} \\
& \mathrm{H}_{2}+\mathrm{O}^{2-} \rightarrow 2 \mathrm{H}_{2} \mathrm{O}+2 e^{-} \\
& \mathrm{CO}+\mathrm{O}^{2-} \rightarrow \mathrm{CO}_{2}+2 e^{-} \\
& \mathrm{CH}_{4}+\mathrm{O}^{2-} \rightarrow \mathrm{CO}+\mathrm{H}_{2}+2 e^{-}
\end{aligned}
$$

Considering the methodology proposed for this paper, it is known that the methane concentration is practically zero when considering the biogas reform. In (11) does not occur in this study and can be neglected to estimate the mass flow rates of the cogeneration system. In (12) to (17) were used to calculate the mass flow rates of the fuel cell. According to (12), the number of moles of oxygen is calculated from the number of electrons, the number of cells $(n)$ and the intensity of electric current in the circuit $(i)$.

$$
\begin{aligned}
& \dot{n} O_{2}=\frac{i \times n}{4 F} \\
& \dot{m} O_{2}=\frac{\dot{n} O_{2} \times M M_{O_{2}}}{10^{3}}
\end{aligned}
$$




$$
\begin{aligned}
& \dot{m}_{\text {air }}=\frac{\dot{m} O_{2} \times \lambda}{0.23} \\
& \dot{n} O_{2}=\frac{i \times n}{2 F}=\dot{n}_{H_{2}}+\dot{n}_{C O} \\
& \dot{m}_{H_{2}}=\frac{\dot{n}_{\text {anode }}+M M_{H_{2}}}{\mu_{f}+10^{3}} \times 0.79 \\
& \dot{m}_{C O}=\frac{\dot{n}_{\text {anode }}+M M_{C O}}{\mu_{f}+10^{3}} \times 0.21 \\
& \mu_{f}=\frac{\dot{m}_{\text {anode }}}{\dot{m}_{\text {total }}}
\end{aligned}
$$

The mass of oxygen can be determined using (13). The mass of oxygen, considering $77 \%$ nitrogen gas and $23 \%$ oxygen gas by mass, is calculated using (14). The excess air used in the study was $100 \%(\lambda=2)$. The molar flux of the fuel at the anode by (15). The molar flux at the anode is equal to the sum of the molar flux of hydrogen and carbon monoxide present in the reformed fuel. The respective concentrations were considered: $\mathrm{H}_{2}=0.79$ and $\mathrm{CO}=0.21$ to determine these fluxes. The calculations are shown in (16) and (17). In order to estimate the mass fluxes of the anode gasses, the fuel utilization factor must be considered since the consumption is not complete. The fuel utilization factor is calculated using (18) above.

\subsection{Combustion chamber}

The function of the combustion chamber is to increase the efficiency of the useful heat generation system by producing hot water at a temperature of $60^{\circ} \mathrm{C}$. The combustion of the combustible waste contained in the exhaust gases of the fuel cell anode takes place in the combustion chamber. In this work, an isobaric combustion process was considered, where the enthalpy of the products is equal to the enthalpy of the reactants. The chemical reactions in the combustion chamber are shown in (19) to (21).

$$
\begin{aligned}
& \mathrm{CH}_{4}+2 \mathrm{O}_{2} \rightarrow \mathrm{CO}_{2}+\mathrm{H}_{2} \mathrm{O} \\
& \mathrm{CO}+\frac{1}{2} \mathrm{O}_{2} \rightarrow \mathrm{CO}_{2} \\
& \mathrm{H}_{2}+\frac{1}{2} \mathrm{O}_{2} \rightarrow \mathrm{H}_{2} \mathrm{O} \\
& 0.146 \mathrm{H}_{2}+0.039 \mathrm{CO}+0.469 \mathrm{CO}_{2}+0.014 \mathrm{H}_{2} \mathrm{O}+0.370 \mathrm{O}_{2}+2.782 \mathrm{~N}_{2} \\
& \rightarrow 0.509 \mathrm{CO}_{2}+0.16 \mathrm{H}_{2} \mathrm{O}+0.278 \mathrm{O}+2.782 \mathrm{~N}_{2}
\end{aligned}
$$

The overall reaction and stoichiometric combustion equilibrium are shown in (22). The combustion chamber products have the following molar concentrations. anode: $22 \% \mathrm{H}_{2} ; 70 \% \mathrm{CO}_{2} ; 2 \% \mathrm{H}_{2} \mathrm{O}$; and $6 \% \mathrm{CO}$ and cathode: $88 \% \mathrm{~N}_{2}$; and $12 \% \mathrm{O}_{2}$. The result of the stoichiometric balance and the molar concentrations of the reaction products are: $14 \% \mathrm{CO}_{2} ; 4 \% \mathrm{H}_{2} \mathrm{O} ; 75 \% \mathrm{~N}_{2} ;$ and $7 \% \mathrm{O}_{2}$.

\subsection{Fuel cell performance}

The technical analysis of the fuel cell has been carried out using the concepts of the 1st and 2nd laws of thermodynamics and using the concepts relevant to fuel cells. The reaction between hydrogen and oxygen that takes place in the fuel cell produces water and releases electrical energy, which is characterized by thermodynamic concepts such as enthalpy and Gibbs free energy. Gibbs free energy theory (G) was proposed in 1878 by the American physicist Josiah Willard Gibbs with the aim of evaluating the spontaneity of a thermodynamic system. Gibbs free energy (G) is calculated by (23). The variation of Gibbs free energy can be calculated from the enthalpies of formation and entropies at a given temperature, as shown in (24). The electrochemical reactions of the variation of enthalpies of formation are described in (25) and (26), while the variation of entropies is shown in (27) and (28). Enthalpy, (29), and entropy, (30), vary with temperature.

$$
\begin{aligned}
& G=H-\mathrm{TS} \\
& \Delta \bar{g}_{f}=\Delta \bar{h}_{f}-\Delta \mathrm{T} \overline{\mathrm{S}} \\
& \Delta \bar{h}_{f}=\left(\bar{h}_{f}\right)_{\mathrm{H}_{2} O}-\left(\bar{h}_{f}\right)_{H_{2}}-\frac{1}{2}\left(\bar{h}_{f}\right)_{O_{2}}
\end{aligned}
$$




$$
\begin{aligned}
& \Delta \bar{h}_{f}=\left(\bar{h}_{f}\right)_{C O_{2}}-\left(\bar{h}_{f}\right)_{C O}-\frac{1}{2}\left(\bar{h}_{f}\right)_{O_{2}} \\
& \Delta \overline{\mathrm{S}}=(\overline{\mathrm{S}})_{\mathrm{H}_{2} O}-(\overline{\mathrm{S}})_{H_{2}}-\frac{1}{2}(\overline{\mathrm{S}})_{O_{2}} \\
& \Delta \overline{\mathrm{S}}=(\overline{\mathrm{S}})_{C O_{2}}-(\overline{\mathrm{S}})_{C O}-\frac{1}{2}(\overline{\mathrm{S}})_{O_{2}} \\
& \bar{h}_{T}=\bar{h}_{298.15}+\int_{298.15}^{T} \bar{C}_{p} d T \\
& \bar{S}_{T}=\overline{\mathrm{S}}_{298.15}+\int_{298.15}^{T} \frac{1}{2} \mathrm{~T} \times \bar{C}_{p} d T \\
& E F=\frac{\Delta \bar{g}_{f}}{n F} \\
& \eta_{\text {Thermodynamic }}=\frac{\Delta G}{\Delta H} \\
& \eta_{\text {electrochemical }}=\frac{E F_{\text {real }}}{E F_{\text {max }}} \\
& \eta_{\text {pratical }}=\frac{W_{\text {electrochemical }}}{\Delta H}=\eta_{\text {Thermodynamic }} \times \eta_{\text {electrochemical }}
\end{aligned}
$$

The electromotive force or open circuit voltage of a fuel cell can be defined by (31). Thermodynamic, electrochemical, and practical efficiencies are shown in (32) to (34). Thermodynamic efficiency is the maximum possible electrical work divided by the enthalpy of the chemical reaction, assuming that this process is reversibly isobaric, according to (32). Electrochemical efficiency is the ratio between the real electromotive force and the maximum possible electromotive force in a fuel cell according to (33). Practical efficiency is calculated from the ratio of real electrical work by the enthalpy of the chemical reaction according to (34).

\subsection{1st and 2 nd law of thermodynamics}

The 1st law of thermodynamics establishes the principles of conservation of energy and mass for evaluating the efficiency of energy systems. In (35) and (36) present the theory of the 1st law of thermodynamics for the steady-state control volume $(\mathrm{CV})$, where kinetic and potential energy changes are not considered.

$$
\begin{aligned}
& \sum \dot{m}_{\text {input }}-\sum \dot{m}_{\text {output }}=0 \\
& \sum \dot{Q}_{c v}-\dot{W}_{c v}+\sum \dot{m}_{\text {input }} \times h_{\text {input }}-\sum \dot{m}_{\text {output }} \times h_{\text {output }}=0
\end{aligned}
$$

In this work, the quality of power dissipation or the occurrence of process irreversibilities was not considered, although they are widespread. Therefore, to evaluate the quality of the energy involved in the process and the irreversibilities of the system, the evaluation according to the principles of the 2 nd law of thermodynamics was used.

\subsection{Physical exergy}

The 2nd law of thermodynamics allows us to say whether or not a process is possible by exergetic analysis and also shows that there is no total equivalence between work and heat. Exergy describes the potential of fluids within a control volume to perform work. Exergy analysis makes it possible to determine the quality of the cogeneration system, considering exergy losses and dissipation. The physical exergy is the maximum amount of work resulting from the most adequate process of a system that is in an initial state until it reaches the reference state, through physical processes involving only thermal interactions with the medium. The physical exergy is calculated using (37), while (38) ignores the variations in kinetic and potential energy.

$$
\text { ex } x_{\text {physical }}=\left(h-T_{o} S+\frac{V^{2}}{2} g Z\right)-\left(h_{0}-T_{o} S_{0}+g Z\right)
$$




$$
\begin{aligned}
& \text { ex physical }=\left(h-h_{0}\right)-T_{o} \times\left(S-S_{0}\right) \\
& \text { ex } x_{\text {hysical }}=c_{p} \times T_{o} \times\left[\left(\frac{T}{T_{o}}\right)-1-\ln \left(\frac{T}{T_{o}}\right)+\ln \left(\frac{P}{P_{o}}\right)^{\left[\frac{\delta-1}{\delta}\right]}\right]
\end{aligned}
$$

The reference condition of the temperature and pressure variables was $25^{\circ} \mathrm{C}$ and $101.3 \mathrm{~Pa}$, respectively. Assuming an ideal gas with constant specific heat, the calculation of the physical exergy of the gases can be performed using (39).

\subsection{Chemical exergy}

Chemical exergy is the maximum amount of work that can be done when a given substance is brought from restricted to unrestricted equilibrium by processes involving only heat and mass transfer with the medium. The chemical exergy was calculated using (40), where $x n$ is the molar fraction of the mixture component and $e_{n}^{c h}$ is the standard chemical exergy. The standard exergies for the substances involved in the proposed cogeneration system are shown in Table 6 . With respect to the flows shown in Table 7, the molar concentrations and mass flow calculations were obtained assuming that streams 1,2 and 3 refer to the biogas feeding the SOFC and having in its composition $60 \% \mathrm{CH}_{4}$ and $40 \% \mathrm{CO}_{2}$ as shown in Table 4, and the mass flow was calculated based on (15) to (17). The air feed of the system, according to flows 5 and 6 , has in its molar composition $79 \% \mathrm{~N}_{2}$ and $21 \% \mathrm{O}_{2}$ and its mass flow was calculated based on (12) to (14).

The molar fractions and flow rates of streams 4 and 7, representing the exhaust gases from the anode and cathode, respectively, were determined based on the stoichiometry of the cell reactions according to (8) to (10). For the exhaust gas mixture corresponding to streams 8,9 and 10, stoichiometric calculations were also performed for the combustor based on (19) to (21), where the reactants are the SOFC exhaust gases and the balance of products is represented by (22). Finally, there is the production of hot water, streams 11,12 and 13 , which by evidence the molar concentration is 1 and the mass flow was determined based on the concepts of energy conservation according to the 1st law of thermodynamics.

$$
\text { ex } x_{\text {chemical }}=\sum x_{n} \times e_{n}^{c h}+R \times T_{o} \times \sum x_{n} \times \ln \left(x_{n}\right)
$$

Table 6. Standard chemical exergies

\begin{tabular}{lc}
\hline \multicolumn{1}{c}{ Component } & Standard Chemical Exergy $[\mathrm{kJ} / \mathrm{kmol}]$ \\
\hline Methane $\left(\mathrm{CH}_{4}\right)$ & 831.650 \\
Hydrogen $\left(\mathrm{H}_{2}\right)$ & 236.100 \\
Water $\left(\mathrm{H}_{2} \mathrm{O}\right)$ & 900 \\
Steam $\left(\mathrm{H}_{2} \mathrm{O}\right)$ & 9.500 \\
Carbon oxide $(\mathrm{CO})$ & 274.857 \\
Carbon dioxide $\left(\mathrm{CO}_{2}\right)$ & 19.870 \\
Oxygen $\left(\mathrm{O}_{2}\right)$ & 3.970 \\
Nitrogen $\left(\mathrm{N}_{2}\right)$ & 720 \\
Air & 11.690 \\
\hline
\end{tabular}

Table 7. Molar concentrations of the proposed system

\begin{tabular}{clccccccc}
\hline Streams & \multicolumn{1}{c}{ Component } & $\mathrm{XH}_{2}$ & $\mathrm{XCO}_{2}$ & $\mathrm{XH}_{2} \mathrm{O}$ & $\mathrm{XCH}_{4}$ & $\mathrm{XCO}$ & $\mathrm{XN}_{2}$ & $\mathrm{XO}_{2}$ \\
\hline 1 & Biogas & - & 0.4 & - & 0.6 & - & - & - \\
2 & Biogas & - & 0.4 & - & 0.6 & - & - & - \\
3 & Biogas & - & 0.4 & - & 0.6 & - & - & - \\
$3(\mathrm{a})$ & Biogas + Steam & - & 0.1 & 0.75 & 0.15 & - & - & - \\
$3(\mathrm{~b})$ & Reformed fuel & 0.36 & 0.09 & 0.44 & - & 0.1 & - & - \\
$4(\mathrm{a})$ & Chemical reaction products & 0.08 & 0.26 & 0.64 & - & 0.02 & - & - \\
4 & Exhaust gases & 0.22 & 0.7 & 0.02 & - & 0.06 & - & - \\
5 & Air & - & - & - & - & - & 0.79 & 0.21 \\
6 & Air & - & - & - & - & - & 0.79 & 0.21 \\
7 & Air SOFC & - & - & - & - & - & 0.88 & 0.12 \\
8 & Exhaust gases & - & 0.14 & 0.04 & - & - & 0.75 & 0.07 \\
9 & Exhaust gases & - & 0.14 & 0.04 & - & - & 0.75 & 0.07 \\
10 & Exhaust gases & - & 0.14 & 0.04 & - & - & 0.75 & 0.07 \\
11 & Water & - & - & 1 & - & - & - & - \\
12 & Water & - & - & 1 & - & - & - & - \\
13 & Water & - & - & 1 & - & - & - & - \\
\hline
\end{tabular}


In Table 7, three hypothetical streams were added (3 (a): biogas + steam), (3 (b): reformed fuel) and (4 (a): SOFC reaction products). These hypothetical streams were added to complete the development of the exergetic analysis considering these three situations. Stream 3 (a) represents the mixture of biogas and steam, which is the input for the reforming process that takes place at the inlet of the cell and has the proportions 1.5/1.0/7.5 for $\mathrm{CH}_{4} / \mathrm{CO}_{2} / \mathrm{H}_{2} \mathrm{O}$ steam to satisfy the $\mathrm{S} / \mathrm{C}$ rate=3. After the reforming of the biogas and before the electrochemical reaction of the fuel cell is the hypothetical stream of point 3 (b). The last hypothetical stream (stream 4 (a)) represents the products of the cell reaction before the moment of using the steam for the anodic recirculation that feeds the reformation, where the molar composition is determined with the stoichiometric equilibrium of the electrochemical reactions.

\subsection{Exergy balance}

The evaluation of the energy balance of the system components followed the reactions as shown in (41) to (44). Exergetic efficiency, as proposed by Bosnjakovic (1965), was evaluated according to (45). Another concept of exergy was also analyzed considering the efficiency of the 2nd law of thermodynamics, which is the relationship between the useful work of the system and the exergy flow of the fuel (biogas), according to (46) and (47) [21], [27], [29]. The useful work is the power produced by the cell minus the auxiliary work done by the compressors, considering an efficiency of $80 \%$, according to (48). The compressor outlet temperature was determined using (49) and the specific heat ratio of the air (air) was determined using (50).

$$
\begin{aligned}
& \dot{E} x_{\text {input }}^{\dot{W}}+\dot{E} x_{\text {input }}^{\dot{Q}}+\sum \dot{m} e_{\text {input }}=\dot{E} x_{\text {output }}^{\dot{W}}+\dot{E} x_{\text {output }}^{\dot{Q}}+\sum \dot{m} e_{\text {output }}+\dot{I} \\
& \dot{E x} \dot{W}=W \\
& \dot{E} x^{\dot{Q}}=W \times\left(\frac{T-T_{o}}{T}\right) \\
& \text { ex }=x_{\text {physical }}+\text { ex } \text { chemical } \\
& \psi=\frac{\dot{\Delta E x_{\text {output }}}}{\dot{\Delta E x_{\text {imput }}}} \\
& \eta=\frac{\dot{W}}{\dot{E} x_{f u e l}} \\
& \eta=\frac{\dot{W}_{\text {SOFC }}-\left(\dot{W}_{\text {compressor } 1}-\dot{W}_{\text {compressor } 2}\right)}{\dot{m}_{\text {fuel }} \times \dot{e x}_{\text {fuel }}} \\
& \dot{W}_{\text {compressor }}=\frac{\dot{m} \times c_{p} \times\left(T_{\text {output }}-T_{\text {input }}\right)}{\eta_{\text {compressor }}} \\
& T_{\text {output }}=T_{\text {input }} \times\left[1+\left(\frac{1}{\eta_{\text {compressor }}}\right)\right] \times\left[\left(\frac{P_{\text {output }}}{P_{\text {input }}}\right)^{\left(\frac{\delta_{\text {air }}-1}{\delta}\right)}-1\right] \\
& \delta_{\text {air }}=\left[\frac{1}{1-\left(\frac{R_{\text {air }}}{C p_{\text {air }}}\right)}\right]
\end{aligned}
$$

\subsection{System efficiency}

The electrical, thermal and global efficiencies of the system were calculated using (51) to (55). The amount of heat recycled to produce hot water was calculated using (53) and the lower heating value (LHV) of the biogas was calculated by proportionality of the composition of the mass of methane in the biogas using (54).

$$
\begin{aligned}
& \eta_{\text {electrical }}=\frac{\dot{W}_{\text {useful }}}{\dot{m}_{\text {fuel }} \times L H V_{f u e l}} \\
& \eta_{\text {termical }}=\frac{\dot{Q}_{\text {useful }}}{\dot{m}_{\text {fuel }} \times L_{H} V_{f u e l}}
\end{aligned}
$$




$$
\begin{aligned}
& \dot{Q}_{\text {useful }}=\dot{m}_{\text {water }} \times\left(h_{\text {hot water }}-h_{\text {cold water }}\right) \\
& L H V_{\text {biogas }}=\% \text { mass }_{C_{4}} \times L H V_{C H_{4}} \\
& \eta_{\text {global }}=\frac{\dot{W}_{u s e f u l}+\dot{Q}_{u s e f u l}}{\dot{m}_{f u e l} \times L H V_{\text {biogas }}} \\
& \eta_{\text {global }}=\eta_{\text {electrical }}+\eta_{\text {thermal }}
\end{aligned}
$$

\section{RESULTS AND DISCUSSION}

The results of the mathematical modeling and the technical performance of the fuel cell were analyzed based on the parameters described in Table 2 and according to the methodology presented in the experimental chapter. The results of the efficiencies as well as the Gibbs free energy are described in Table 8. The fuel cell achieved a thermal efficiency of $71.3 \%$, an electrochemical efficiency of $74.4 \%$, and a practical efficiency of $53.1 \%$. The effect of temperature on the electromotive force of a fuel cell has a negative effect on the maximum voltage. The values for the temperatures of $700^{\circ} \mathrm{C}$ and $1,100^{\circ} \mathrm{C}$ are 1.016 and 0.868 of the electromotive force, respectively. The behavior of the maximum electromotive force as a function of temperature can be seen in Figure 4.

Table 8. SOFC technical performance results

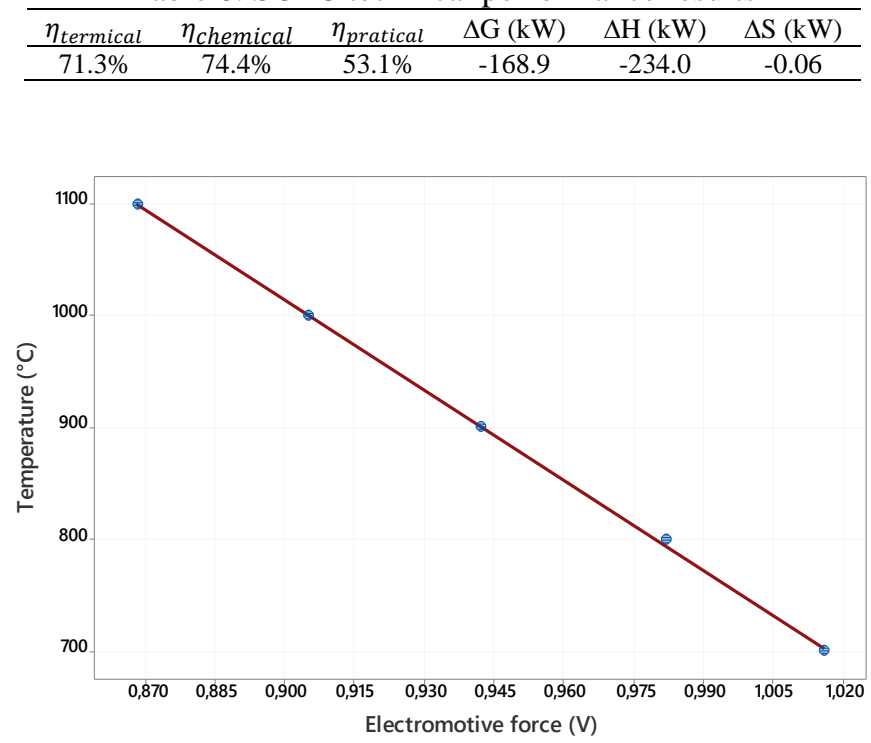

Figure 4. Maximum electromotive force $\mathrm{x}$ temperature

The operating temperature of the selected fuel cell is $900^{\circ} \mathrm{C}$, so the maximum possible electromotive force will be 0.942 . The enthalpies, entropies and exergies of each point in the system are shown in Table 9. The enthalpy and entropy values were used to evaluate the cogeneration system according to the 1st law of thermodynamics and are shown in Table 10. From the efficiencies of electricity and useful heat generation, the overall efficiency is $94.5 \%$. The SOFC efficiency for electricity generation of $52.9 \%$ confirms the expectation of being greater than Carnot cycles on average, as the cell converts chemical energy directly into electrical energy.

The electrical efficiency added with the thermal efficiency of $41.6 \%$ gives an overall efficiency of $94.5 \%$ for the proposed system. It also confirms the expected result of the overall efficiency of the system compared to other published studies using SOFC for cogeneration whose efficiencies are around $90 \%$. According to the 2nd law of thermodynamics and the exergy values presented in Table 9, the exergy balance was performed in each control volume, and the respective irreversibilities and rational efficiency results are presented in Table 11. Heat exchanger 2 was the component with the lowest Bosnjakovic efficiency, at $46.8 \%$; on the other hand, the compressors were the components with the highest Bosnjakovic efficiency, both above $98.4 \%$. 


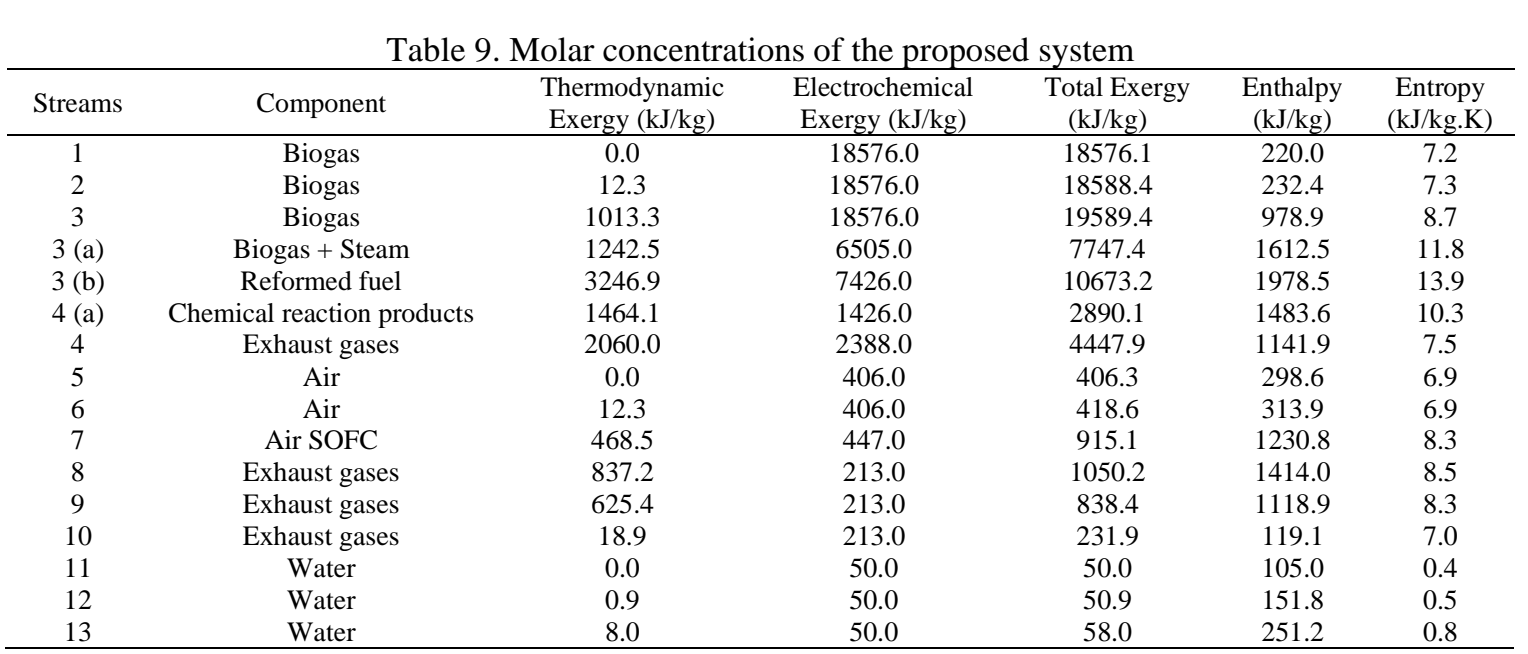

Table 10. Efficiencies according to the 1st law of thermodynamics

\begin{tabular}{ccc}
$\eta_{\text {termical }}$ & $\eta_{\text {electrochemical }}$ & $\eta_{\text {global }}$ \\
\hline $41.6 \%$ & $52.9 \%$ & $94.5 \%$
\end{tabular}

Table 11. Exergy balance, irreversibility and rational efficiency of equipment

\begin{tabular}{lcccc}
\hline \multicolumn{1}{c}{ Equipment } & Input Exergy $(\mathrm{kW})$ & Output Exergy $(\mathrm{kW})$ & Irreversibility $(\mathrm{kW})$ & Exergy Efficiency $(\%)$ \\
\hline Combustion chamber & 181.3 & 117.6 & 63.7 & $64.9 \%$ \\
Compressor 1 & 194.7 & 194.7 & 0.07 & $99.9 \%$ \\
Compressor 2 & 43.2 & 42.5 & 0.7 & $98.5 \%$ \\
Heat exchanger 1 & 402.5 & 258.9 & 143.6 & $64.3 \%$ \\
Heat exchanger 2 & 120.7 & 56.5 & 64.2 & $46.8 \%$ \\
Heat exchanger 3 & 312.3 & 299.0 & 13.2 & $95.8 \%$ \\
\hline
\end{tabular}

\section{CONCLUSION}

It can be concluded that solid oxide fuel cells are suitable for power generation from both energy and cogeneration point of view. The present paper presented a possibility of application of SOFC with internal steam reforming of biogas has been presented, where the high operating temperature and anodic steam recirculation can be used to produce hydrogen. Moreover, it is found that the steam to carbon rate used in internal steam reforming has a direct relationship with the production of hydrogen, i.e., the higher the steam to carbon rate, the greater the mass of hydrogen of the products will be at constant biogas mass flow rate. Regarding the technical aspect, the overall efficiency of the system was over $94 \%$, considering the concepts of the 1st law of thermodynamics, where the electrical efficiency was $52.9 \%$ and the thermal efficiency was $41.6 \%$. With respect to the exergy flows studied, the largest irreversibilities relate, in descending order, to the heat exchanger 2 (hot water generation point using the heat of the exhaust gases), to the heat exchanger cell assembly and to the combustion chamber.

\section{REFERENCES}

[1] S. Bahraminia, M. Anbia and E. Koohsaryan, "Hydrogen sulfide removal from biogas using ion-exchanged nanostructured $\mathrm{NaA}$ zeolite for fueling solid oxide fuel cells," International Journal of Hydrogen Energy, vol. 45, no. 55, pp. 31027-31040, November 2020, doi: 10.1016/j.ijhydene.2020.08.091.

[2] D. Thiruselvi et al., "A critical review on global trends in biogas scenario with its up-gradation techniques for fuel cell and future perspectives," International Journal of Hydrogen Energy, vol. 46, no. 31, pp. 16734-16750, May 2021, doi: 10.1016/j.ijhydene.2020.10.023.

[3] D. Papurello, S. Silvestri and S. Modena, "Biogas trace compounds impact on high-temperature fuel cells short stack performance," International Journal of Hydrogen Energy, vol. 46, no. 12, pp. 8792-8801, February 2021, doi: 10.1016/j.ijhydene.2020.11.273.

[4] G. Yang et al., "Applying bio-electric field of microbial fuel cell-upflow anaerobic sludge blanket reactor catalyzed blast furnace dusting ash for promoting anaerobic digestion," Water Research, vol. 149, pp. 215-224, 2019, doi: 10.1016/j.watres.2018.10.091.

[5] R. N. Nakashima and S. O. Junior, "Multi-objective optimization of biogas systems producing hydrogen and electricity with solid oxide fuel cells," International Journal of Hydrogen Energy, september 2021, in press, doi: 10.1016/j.ijhydene.2021.08.195. 
[6] S. Giarola, O, Forte, A, Lanzini, M. Gandiglio, M. Santarelli and A. Hawkes, "Techno-economic assessment of biogas-fed solid oxide fuel cell combined heat and power system at industrial scale," Applied Energy, vol. 211, pp. 689-704, February 2018, doi: 10.1016/j.apenergy.2017.11.029

[7] N. Chatrattanawet et al., "Performance and environmental study of a biogas-fuelled solid oxide fuel cell with different reforming approaches," Energy, vol. 146, pp. 131-140, March 2018, doi: 10.1016/j.energy.2017.06.125

[8] M. Escudero, C. A. Maffiotte, and J. L. Serranoa, "Long-term operation of a solid oxide fuel cell with $\mathrm{MoNi}_{-} \mathrm{CeO}_{2}$ as anode directly fed by biogas containing simultaneously sulphur and siloxane," Journal of Power Sources, vol. 481, p. 229048, January 2021, doi: 10.1016/j.jpowsour.2020.229048.

[9] S. Sechi et al., "A bottom-up appraisal of the technically installable capacity of biogas-based solid oxide fuel cells for self power generation in wastewater treatment plants," Journal of Environmental Management, vol. 279, p. 111753, February 2021, doi: 10.1016/j.jenvman.2020.111753.

[10] W. Cardoso, et al. "Mathematical modelling to predict Fuel consumption in a blast furnace using artificial neural networks, Integrated Emerging Methods of Artificial Intelligence and Cloud Computing," Smart Innovation, Systems and Technologies. Springer, London, UK, 2021, in press.

[11] G. Oluleye, M. Gandiglio, M. Santarelli and A. Hawkes, "Pathways to commercialisation of biogas fuelled solid oxide fuel cells in European wastewater treatment plants," Applied Energy, vol. 282, Part A, p. 116127, January 2021, doi: 10.1016/j.apenergy.2020.116127.

[12] D. Gu, G. Zhang and J. Zou, "High temperature thermo-photocatalysis driven carbon removal in direct biogas fueled solid oxide fuel cells," Chinese Chemical Letters, 2021, doi: 10.1016/j.cclet.2021.01.050.

[13] K. Huang and S. Singhal, "Cathode-supported tubular solid oxide fuel cell technology: A critical review," Journal of Power Sources, vol. 237, pp. 84-97, September 2013, doi: 10.1016/j.jpowsour.2013.03.001.

[14] H. Zeng et al., "Biogas-fueled flame fuel cell for micro-combined heat and power system," Energy Conversion and Management, vol. 148, pp. 701-707, September 2017, doi: 10.1016/j.enconman.2017.06.039.

[15] E. O. Koroglu, O. K. Ozdemir, B. Ozkaya and A. Demir, "An integrated system development including PEM fuel cell/biogas purification during acidogenic biohydrogen production from dairy wastewater," International Journal of Hydrogen Energy, vol. 44, no. 32, pp. 17297-17303, June 2019, doi: 10.1016/j.ijhydene.2019.01.291.

[16] H. N. C. da Silva, D. M. Prata, G. B. A. Lima, L. P. Zotes and L. V. Mattos, "A techno-economic evaluation of the energy generation by proton exchange membrane fuel cell using biogas reforming," Journal of Cleaner Production, vol. 200, pp. 598-608, November 2018, doi: 10.1016/j.jclepro.2018.07.120.

[17] X. Ding, X. Lv and Y. Weng, "Coupling effect of operating parameters on performance of a biogas-fueled solid oxide fuel cell/gas turbine hybrid system," Applied Energy, vol. 254, p. 113675, November 2019, doi: 10.1016/j.apenergy.2019.113675.

[18] S. Kondaveeti et al., "Conversion of simulated biogas to electricity: Sequential operation of methanotrophic reactor effluents in microbial fuel cell," Energy, vol. 189, p. 116309, December 2019, doi: 10.1016/j.energy.2019.116309.

[19] Z. Lyu, Y. Wang, Y. Zhang and M. Han, "Solid oxide fuel cells fueled by simulated biogas: Comparison of anode modification by infiltration and reforming catalytic layer," Chemical Engineering Journal, vol. 393, p. 124755, August 2020, doi: 10.1016/j.cej.2020.124755.

[20] A. S. Mehr, A. Moharramian, S. Hossainpour and D. A. Pavloc, "Effect of blending hydrogen to biogas fuel driven from anaerobic digestion of wastewater on the performance of a solid oxide fuel cell system," Energy, vol. 202, p. 117668, July 2020, doi: 10.1016/j.energy.2020.117668.

[21] A. Saengprajak, A. Katcharoen, W. Chockua and J. Piamdee, "Prospective study of application the direct-biogas solid oxide fuel cell system to the biogas plant in Thailand," Energy Procedia, vol. 158, pp. 978-983, February 2019, doi: 10.1016/j.egypro.2019.01.239.

[22] H. Wasajja, R. E. F. Lindeboom, J. B. van Lier and P. V. Aravind, "Techno-economic review of biogas cleaning technologies for small scale off-grid solid oxide fuel cell applications," Fuel Processing Technology, vol. 197, p. 106215, January 2020, doi: 10.1016/j.fuproc.2019.106215.

[23] F. Loureiro et al., "Nickel-copper based anodes for solid oxide fuel cells running on hydrogen and biogas: Study using ceria-based electrolytes with electronic short-circuiting correction," Journal of Power Sources, vol. 438, p. 227041, October 2019, doi: 10.1016/j.jpowsour.2019.227041.

[24] A. Rafique, R. Raza, A. Ali, M. A. Ahmad and M. Syväjärvi, "An efficient carbon resistant composite $\mathrm{Ni}_{0.6} \mathrm{Zn}_{0.4} \mathrm{O}_{2}$ ${ }_{8}$-GDC anode for biogas fuelled solid oxide fuel cell," Journal of Power Sources, vol. 438, p. 227042, October 2019, doi: 10.1016/j.jpowsour.2019.227042.

[25] T. G. H. Nguyen et al., "Development of paper-structured catalyst for application to direct internal reforming solid oxide fuel cell fueled by biogas," International Journal of Hydrogen Energy, vol. 44, no. 21, pp. 10484-10497, April 2019, doi: 10.1016/j.ijhydene.2019.02.134.

[26] K. Girona, J. Laurencin, J. Fouletier and F. Lefebvre-Joud, "Carbon deposition in $\mathrm{CH}_{4} / \mathrm{CO}_{2}$ operated SOFC: Simulation and experimentation studies," Journal of Power Sources, vol. 210, pp. 381-391, July 2012, doi: 10.1016/j.jpowsour.2011.12.005

[27] S. Saadabadi, A. T. Thattai, L. Fan, R. E. F. Lindeboom, H. Spanjers and P. V. Aravind, "Solid Oxide Fuel Cells fuelled with biogas: Potential and constraints," Renewable Energy, vol. 134, pp. 194-214, April 2019, doi: 10.1016/j.renene.2018.11.028

[28] B. Bochentyn, D. Szymczewska, T. Miruszewski, Sea-Fue Wang and P. Jasiński, "The influence of synthesis method on the microstructure and catalytic performance of $\mathrm{Y}_{0.07} \mathrm{Sr}_{0.93} \mathrm{Ti}_{0.8} \mathrm{Fe}_{0.2} \mathrm{O}_{3-\delta}$ in synthetic biogas operated solid oxide fuel cells," Materials Research Bulletin, vol. 100, pp. 49-55, April 2018, doi: 10.1016/j.materresbull.2017.12.002. 
[29] M. Chlipała, P. Błaszczak, S.-F. Wang, P. Jasiński, and B. Bochentyna, "In situ study of a composition of outlet gases from biogas fuelled Solid Oxide Fuel Cell performed by the Fourier Transform Infrared Spectroscopy," International Journal of Hydrogen Energy, vol. 44, no. 26, pp. 13864-13874, May 2019, doi: 10.1016/j.ijhydene.2019.03.243.

\section{BIOGRAPHIES OF AUTHORS}
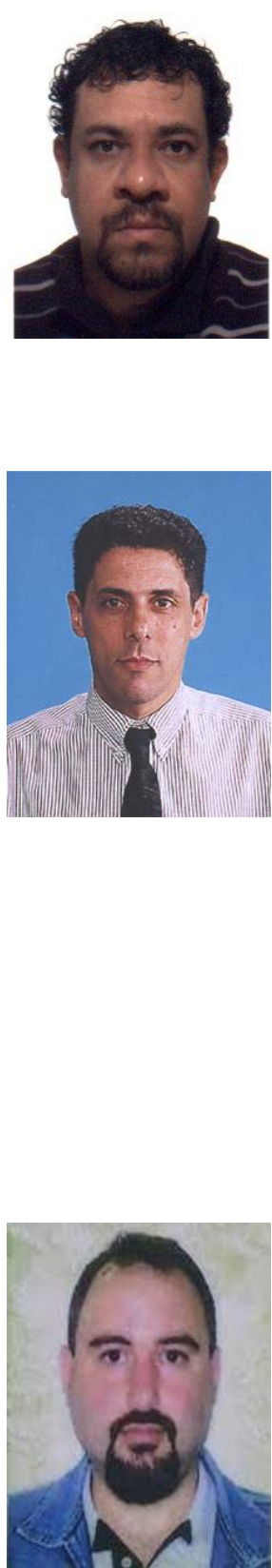

Wandercleiton Cardoso is a Ph. D student at the University of Genoa (Italy) since 2019. He received his Bachelor's degree at the University of Vila Velha (Brazil) in 2009, then his MSc. at Federal Institute of Espirito Santo (Brazil), both in Materials and Metallurgy Engineering. He specialised in Electrical Engineering (2019) and Environmental Engineering (2011), and has an MBA in Project Management (2018) at Universidade Cândido Mendes (Brazil). He also has a technical background in Electrotechnics (2019) at CEDTEC Educational Center (Brazil), a Technician in Mechanics (2002) and a Technician in Metallurgy and Materials (2004) at Federal Institute of Espirito Santo (Brazil) and is also qualified as a Level I Mechanic (2004) and Inspector of Mechanical Maintenance (2008) at Brazilian Maintenance Association. He has experience in chemical industry, steel, mining, ports and maintenance (21 years experience). He has worked as Senior Project Manager at AcerlorMittal (2001 to 2010) and Vale (2010 to 2020) and as a lecturer in engineering courses (2009 to 2021) in disciplines related to research lines on transportation phenomena, industrial chemistry, engineering materials and enterprise logistics.

Renzo Di Felice is an Associate Professor of Applied Chemical Kinetics at the University of Genoa (Italy) since 1992. He received his Batchelor Degree in Chemical Engineering from the University of L'Aquila (Italy) in 1981, then his Ph.D. and D.Sc. (Eng) from the University of London (U.K.) in 1988 and 1997, respectively, both in Chemical Engineering. After a brief industrial experience shortly after his first degree and before moving to Genoa, Renzo Di Felice held a position as "Ricercatore Universitario" (equivalent to Assistant Professor) at the University of L'Aquila from 1983 to 1992. During this time, he spent two years in the Department of Chemical and Biochemical Engineering, University College London, as a research assistant. Other, more recent experiences outside Italy include teaching and research stays at the University of Addis Ababa (Ethiopia) and at the National University of Singapore (Singapore), where he was Visiting Associate Professor. Over the years he has taught various Chemical Engineering subjects at university level. Renzo Di Felice 's research activity has focused on the fluid dynamic behaviour of two-phase suspensions, with particular reference to the fluidization of solid particles and to the sedimentation velocity of monoscale spheres. One of the most important practical applications of solid-liquid systems is in the field of biotechnology, and a good part of his recent work is specifically directed in this direction. Renzo Di Felice has authored more than sixty papers in international scientific journals, including the invited review paper on the fluid dynamic behaviour of liquid fluidized suspensions published in Chemical Engineering Science. He is a member of the American Institute of Chemical Engineers (U.S.A.), the institutions of Chemical Engineers (U.K.), and the Italian Association of Chemical Engineering (AIDIC), for which he is nationally responsible of Chemical Reaction Division.

Raphael Colombo Baptista is MSc. student in Metallurgy and Materials Engineering at Federal Institute of Espirito Santo (Brazil), Postgraduate in Production Engineering (2021) at Estácio de Sá University (Brazil), Graduated in Metallurgy and Materials Engineering (2012) at Vila Velha University (Brazil). Technician in Metallurgy at Federal Technical School of Espírito Santo. Qualified as Black and Green Belt Lean Six Sigma at Seta Desenvolvimento Gerencial (20172019). Experience in the steel industry and processes, experience in materials and Metallurgical Engineering, with a focus on metallurgical facilities and equipment, working mainly on the following topics: ore Reduction, management of Storage yards and services, operations and production control, management of projects, process optimization, blow-in and blow-down of blast Furnaces. 